\title{
Penerapan Bimbingan Berkelanjutan untuk Meningkatkan Kemampuan Melaksanakan Asesmen Autentik pada Guru di SD
}

\section{Gusti Nyoman Reniasih}

1SD Negeri 1 Banjar Tegal, Singaraja, Indonesia

A R T I C L E I N F O

Article history:

25 December 2019

Received in revised form 01 January 2020

Accepted 25 January 2020

Available online 28

February 2020

\section{Kata Kunci:}

bimbingan berkelanjutan,

asesmen autentik

Keywords:

TTW, multimedia, speaking skills

perempuan. Data kemampuan guru menyusun bimbingan berkelanjutan nilai rata-rata kemampuan guru sebesar 62,72 meningkat melaksanakan asesmen autentik diperoleh melalui penilaian dokumen asesmen yang telah disusun dengan menggunakan instrumen observasi, selanjutnya dianalisis dengan menggunakan metode deskriptif kuantitatif disajikan dalam bentuk rata-rata nilai kemampuan guru melaksanakan asesmen autentik. Penelitian dilaksanakan selama dua siklus, memperoleh simpulan bahwa kemampuan guru SD Negeri 1 Banjar Tegal dalam melaksanakan asesmen autentik dapat ditingkatkan melalui penerapan bimbingan berkelanjutan. Hal ini terlihat dari peningkatan kemampuan guru dalam melaksanakan asesmen autentik yaitu sebelum dilaksanakan pada siklus I menjadi 69,59 dan meningkat lagi pada siklus II menjadi 78,92.

\section{A B S T R A C T}

Facts showed that the assessment instruments owned by teachers were incomplete. This was reinforced by the results of interviews that had been conducted and found several problems related to teachers who had not applied authentic assessment in accordance with the 2013 curriculum. This problem was evidenced by the results of assessments owned by teachers and the results showed that there were still many assessment notes that were empty and only a few have been be equipped. This action research aimed to improve the teachers' ability in carried out the authentic assessment of SD Negeri 1 Banjar Tegal on the first semester students in academic year 2019/2020 through the application of ongoing guidance. The subjects in this research were 7 elementary school teachers in Banjar Tegal consisted of 2 male teachers and 5 female teachers. Teachers'ability mean score in arranging ongoing guidance was 62.72 increased in carrying out authentic assessments obtained through the document assessment that had been arranged by using observation instruments. The research was carried out over two cycles, for the first was made the conclusion that the teachers'ability of SD Negeri 1 Banjar Tegal in carrying out authentic assessments could be improved through the application of ongoing guidance. This could be seen from the improvement of the teachers'ability in carrying out the authentic assessment before implementing it on cycle I to 69.59 and improved again on cycle II to 78.92 . 



\section{Pendahuluan}

Kurikulum 2013 menjelaskan beberapa karakteristik pendidikan anak usia dini salah satunya ialah menggunakan penilaian autentik (authentic asessment). Penilaian autentik adalah penilaian yang dilakukan secara komprehensif untuk menilai sikap, pengetahuan, dan keterampilan (Amin et al., 2016) . Autentik berarti keadaan sebenarnya, yaitu kemampuan atau keterampilan yang dimiliki oleh peserta didik. Penilaian autentik memiliki relevansi kuat terhadap pendekatan ilmiah dalam pembelajaran sesuai dengan tuntutan kurikulum 2013. Untuk pemenuhan pendidikan anak usia dini yang berkualitas harus mengikuti standar PAUD berdasarkan peraturan saat ini diantaranya adanya sarana pendidikan (Zahro, 2015).

Penilaian autentik ini dilakukan secara sistematis, terukur, berkelanjutan serta menyeluruh tentang pertumbuhan dan perkembangan anak (Beata Palmin, Maria Rahayu Anwar, 2019). Salah satu prinsip yang digunakan dalam penilaian ini adalah prinsip berkesinambungan dimana dilakukan secara terencana, bertahap dan terus menerus untuk mendapatkan gambaran tentang pertumbuhan dan perkembangan anak. Penilaian autentik dilakukan oleh guru dalam bentuk penilaian ceklis, observasi, unjuk kerja, catatan anekdot, hasil karya dan pelaporan.

Kebanyakan guru masih menggunakan pendekatan konvensional dan penilaian tradisional yang hanya berpusat pada ranah kognitif siswa saja. Guru seharusnya menyadari diperlukan adanya perubahan paradigma pembelajaran yang terjadi di dalam kelas dari pembelajaran yang berpusat pada guru menjadi pembelajaran yang berpusat pada siswa yang sangat dipengaruhi oleh penguasaan guru tentang landasan pembelajaran yang mencakup konsep belajar, mengajar, pembelajaran, konsep pendekatan, strategi, model, metode, teknik pembelajaran, teori-teori belajar serta standar pendidikan (Marhaeni, 2015).

Asesmen autentik merupakan ciri khas Kurikulum 2013. Penilaian autentik ini merupakan penilaian yang dilakukan secara komprehensif untuk menilai dari masukan (input), proses, dan keluaran (output) pembelajaran. Penilaian autentik harus mencerminkan masalah dunia nyata, bukan dunia sekolah (Hajaroh et al., 2018). Menggunakan berbagai cara dan kriteria yang holistik (kompetensi utuh merefleksikan pengetahuan, ketrampilan, dan sikap). Mueller (Yusuf, 2015) menyatakan penilaian autentik merupakan a form of assessment in wich students are asked to perform real-world task that demonstrate meaningful aplication of essential knowledge and skills. Jadi, asesmen atau penilaian autentik merupakan suatu bentuk tugas yang meminta pembelajar untuk menunjukan kinerja sebagaimana dilakukan di dunia nyata secara bermakna yang merupakan penerapan esensi pengetahuan dan keterampilan.

Dalam penilaiannya, seorang guru tidak hanya mengetahui hasil dari kinerjanya tetapi juga mengamati proses peserta didik. Peserta didik adalah pusat pembelajaran dan guru harus memahami dengan benar proses penilaian autentik karena guru sebagai pelaku pelaksanaan penilaian (Ruslan et al., 2016). Data yang dikumpulkan guru melalui kegiatan penilaian bukanlah untuk mencari informasi tentang belajar peserta didik. Pembelajaran yang benar ditekankan pada upaya membantu siswa agar mampu mempelajari (learning how to learn), bukan ditekankan pada diperolehnya sebanyak mungkin informasi di akhir periode pembelajaran.

Asesmen autentik juga dikenal sebagai asesmen kinerja (performance assessment). Asesmen kinerja merupakan bentuk asesmen yang menekankan kinerja siswa yang berhubungan dengan situasi yang sebenarnya, dan dapat mengetahui sikap siswa yang diharapkan, serta memungkinkan untuk mengukur keterampilan siswa secara kompleks (Palm, 2008)). Hal ini sebagaimana yang dikemukakan oleh (Arifin, 2014) yakni bahwa performance assessment dapat digunakan untuk mengetahui tingkat penguasaan keterampilan siswa melalui tes penampilan atau demonstrasi, maupun kerja nyata.

Fakta di lapangan menunjukkan bahwa instrument penilaian yang dimiliki guru tidak lengkap. Hal ini diperkuat dengan hasil wawancara yang telah dilakukan ditemukan beberapa masalah terkait guru yang belum menerapkan penilaian autentik sesuai dengan kurikulum 2013. Hal ini dibuktikan dengan menunjukkan hasil penilaian yang dimiliki guru, hasilnya masih banyak catatan penilaian yang kosong dan hanya beberapa anak yang diisi, mereka juga mengaku kesulitan dalam melakukan pencatatan penilaian, itupun tidak semua anak. Peneliti mendapatkan beberapa guru yang melakukan catatan penilaian dari semester kemarin yang belum terisi semua tetapi anak sudah menerima rapor. Guru sudah mengetahui bahwa penilaian autentik dilakukan secara langsung, namun mereka mengatakan bahwa masih memiliki kesulitan dalam waktu penilaian yang dilakukan setiap hari selama proses pembelajaran berlangsung. Kesulitan ini ditunjukan dengan jawaban guru ketika menjawab pertanyaan tentang ketercapaian penilaian dalam kurikulum 2013. Hal ini berdampak pada hasil penilaian guru yang tidak autentik. Guru memberikan penilaian pada siswa dengan melihat kemampuan siswa secara menyeluruh. 
Guru adalah kunci utama untuk menyukseskan penerapan kurikulum tersebut. Seharusnya komunikasi antar guru untuk memahamkan format perencanaan, penilaian dan evaluasi harus sering dilakukan, karena hal tersebut sangat penting untuk mencapai terlaksananya kurikulum 2013. Masih banyak guru yang belum memahami tugas, fungsi, kompetensi dan keterampilan yang ada dalam kurikulum 2013, yang selayaknya harus dikuasai guru. Kelemahan ini tampak dalam rendahnya kemampuan guru, yang belum siap menghadapi perubahan kurikulum.

Ketidakmampuan guru melaksanakan asesmen autentik tersebut harus diatasi. Dari beberapa alternatif metode dan strategi untuk mengatasi permasalahan tersebut, tindakan yang dipilih adalah dengan menerapkan teknik bimbingan berkelanjutan. Bimbingan merupakan sarana yang dirancang untuk memperbaiki kinerja dan perilaku seseorang, baik secara formal maupun informal. Melalui bimbingan diharapkan adanya peningkatan pengetahuan, kemampuan, dan perilaku yang mampu mengantisipasi perubahan yang terjadi dalam perkembangan IPTEK saat ini (Sahertian, 2008).

Bimbingan melibatkan peserta dan fasilitator dalam dialog satu lawan satu dan mengikuti suatu proses yang tersusun, diarahkan pada tanggung jawab memelihara kemajuan dan kinerja yang baik serta hubungan kerja positif antara fasilitator dan staf. Seperti disebutkan oleh Muniaji (2014) kegiatan ini bertujuan agar peserta dapat 1) Menstimulan pengembangan keterampilan peserta secara individual, 2) Membantu peserta menggunakan pekerjaan sebagai pengalaman pembelajaran dengan bimbingan dan mengembangkan professional peserta, 3) Memberi kesempatan kepada peserta untuk melengkapi pekerjaan yang diberikan fasilitator dan pada saat yang sama mempersiapkan keterampilan peserta dalam mengambil tanggung jawab dan pekerjaan mendatang, dan 4) Meningkatkan kemampuan kemandirian belajar dari peserta dan mengatasi permasalahan yang dihadapi mereka.

Penelitian ini dudukung oleh penelitian yang dilakukan oleh (Suharningsih, 2016) yang melaksankana penelitian dengan judul "Pelaksanaan Bimbingan Berkelanjutan Sebagai Upaya Meningkatkan Kompetensi Guru dalam Menyusun Rencana Pelaksanaan Pembelajaran Di SD N Bandungrejo 1 Pada Semester Gasal Tahun Pelajaran 2014/2015". Berdasarkan hasil analisis data ditemukan hasil penelitian bahwa bimbingan berkelanjutan dapat meningkatkan kompetensi guru dalam menyusun RPP. Hal itu dapat dibuktikan dari hasil observasi/pengamatan yang memperlihatkan bahwa terjadi peningkatan kompetensi guru dalam menyusun RPP dari siklus ke siklus yaitu dari data awal 37,37 $\%$ menjadi $44,44 \%$ pada siklus I, dan meningkat menjadi 76,76 \% pada siklus II.

Melalui kegiatan bimbingan berkelanjutan dapat mendorong kemampuan masing-masing individu sesuai dengan minatnya serta lebih termotivasi dan bertanggung jawab untuk melakukan keterampilan yang baru dipelajari karena bimbingan berlangsung terus menerus dan personal. Bimbingan berkelanjutan dapat dilakukan secara individu maupun kelompok. Pada penelitian ini guru akan dibimbing secara berkenjutan mulai dari penanaman konsep tentang asesmen autentik, bagaimana merancang atau menyusun asesmen autentik, sampai dengan bagaimana melaksanakan asesmen autentik tersebut. Bimbingan berkelanjutan ini diharapkan dapat meningkatkan kemampuan guru SD Negeri 1 Banjar tegal dalam melaksanakan asesmen autentik.

Dari uraian di atas dengan memperhatikan permasalahan dalam penelitian ini dapat dirumuskan permasalahan yaitu apakah penerapan bimbingan berkelanjutan dapat meningkatkan kemampuan melaksanakan penilaian autentik pada guru SD Negeri 1 Banjar Tegal semester I tahun pelajaran 2019/2020?

Berdasarkan pada rumusan masalah penelitian di atas, maka tujuan penelitian adalah untuk meningkatkan kemampuan melaksanakan penilaian autentik pada guru SD Negeri 1 Banjar Tegal semester I tahun pelajaran 2019/2020 melalui penerapan bimbingan berkelanjutan.

\section{Metode}

Penelitian ini termasuk penelitian tindakan sekolah. Elliot memaparkan action research pertama kalinya diperkenalkan oleh Kurt Lewin dengan menggunakan siklus spiral. Adapun langkah-langkahnya terdiri dari perencanaan (planning), pelaksanaan (acting), pengamatan (observing), dan refleksi (reflecting). Model ini selanjutnya dikembangkan oleh Kemmis sehingga langka-langkah kegiatannya menjadi : 1). Mengidentifikasi gagasan/permasalahan umum, 2). Menentukan fakta, 3). Membuat perencanaan umum, 4). Mengembangkan langkah tindakan pertama, 5). Mengimplementasikan tindakan pertama, 6). Mengevaluasi, dan 7). Merevisi perencanaan umum. Penelitian ini dilakukan dalam dua siklus dan masing-masing siklus terdiri atas: perencanaan, pelaksanaan, observasi dan refleksi. Secara rinci prosedur penelitian mengikuti langkah-langkah sebagai berikut.

Pada tahap perencanaan tindakan pertama digunakan untuk mengetahui kemampuan guru dalam melaksanakan asesmen autentik. Hal ini dilakukan dengan cara menilai RPP yang biasa disusun pada bagian penilaian. Adapun langkah-langkah yang ditempuh dalam siklus pertama adalah guru ditugaskan 
mengumpulkan masing-masing satu eksemplar RPP sesuai dengan kelas yang diampu, kemudian peneliti menilai masing-masing RPP pada komponen penilaian dengan menggunakan lembar observasi. Selanjutnya guru menerima RPP yang sudah dinilai berikut hasil penilaiannya, kemudian guru mendiskusikan penyusunan penilaian dengan merevisi bagian-bagian yang masih dianggap kurang.=, dilanjutkan dengan mengadakan tindakan balikan dan tindak lanjut.

Tapap pelaksanaan siklus ini, kegiatan-kegiatan yang dilaksanakan adalah guru diberikan tugas menyusun RPP sesuai dengan kelas yang diampu, kemudian peneliti melakukan observasi ketika guru sedang melaksankan proses pembelajaran. Observasi difokuskan pada komponen penilaian. Dalam kegiatan pengamatan observasi peneliti menilai asemen autentik hasil diskusi dan mengamati proses penilaian yang dilakukan oleh guru. Penilaian ini dimaksudkan untuk memperoleh data pada bagianbagian manakah guru masih lemah dalam melaksanakan asemen autentik. Pada kegiatan refleksi guru dan peneliti berdiskusi untuk menemukan kendala yang diatasi dan solusi yang bisa digunakan.

Penelitian tindakan sekolah ini dilaksanakan di SD Negeri 1 Banjar Tegal tempat penulis bertugas sebagai kepala sekolah. Pelaksanan penelitian tindakan sekolah ini dilaksanakan pada semester I tahun pelajaran 2019/2020. Subjek dari penelitian ini adalah guru-guru SD Negeri 1 Banjar Tegal yang berjumlah 7 orang yang terdiri dari 2 orang guru laki-laki dan 5 orang guru perempuan. Sedangkan objek penelitiannya adalah tentang kemampuan guru dalam melaksanakan asemen autentik.

Untuk memperoleh data dan informasi yang jelas terhadap tindakan yang dilakukan, maka penelitian ini menggunakan teknik pengumpulan data melalui observasi. Data yang diperoleh dari observasi tersebut adalah mengenai kemampuan guru dalam melaksanakan asesmen autentik.

Adapun instrumen yang digunakan untuk memperoleh data tentang kemampuan guru dalam melaksanakan asesmen autentik adalah berupa lembar observasi yang dikembangkan sendiri oleh peneliti mengacu pada pelaksanaan asemen autentik. Kisi-kisi lembar observasi ditunjukkan pada tabel 1.

Tabel 1. Kisi-kisi Lembar Observasi

\begin{tabular}{|c|c|c|c|c|}
\hline No & Komponen & Indikator & Jumlah Butir & No. Item \\
\hline \multirow[t]{4}{*}{1} & Perencanaan & Rancangan penilaian & 2 & 1,2 \\
\hline & Penilaian & Rumusan indikator pencapaian & 5 & $3,4,5,6,7$ \\
\hline & Kompetensi Sikap & Teknik dan Instrumen penilaian & 2 & 8,9 \\
\hline & & Prosedur pengolahan hasil penilaian & 3 & $10,11.12$ \\
\hline \multirow[t]{4}{*}{2} & Perencanaan & Rancangan penilaian & 2 & 1,2 \\
\hline & Penilaian & Rumusan indikator pencapaian & 5 & $3,4,5,6,7$ \\
\hline & Kompetensi & Teknik dan Instrumen penilaian & 2 & 8,9 \\
\hline & Pengetahuan & Prosedur pengolahan hasil penilaian & 3 & $10,11 \cdot 12$ \\
\hline \multirow[t]{4}{*}{3} & Perencanaan & Rancangan penilaian & 2 & 1,2 \\
\hline & Penilaian & Rumusan indikator pencapaian & 5 & $3,4,5,6,7$ \\
\hline & Kompetensi & Teknik dan Instrumen penilaian & 2 & 8,9 \\
\hline & Keterampilan & Prosedur pengolahan hasil penilaian & 2 & 10,11 \\
\hline \multirow[t]{2}{*}{4} & Pelaksanaan & Penginformasian sistem penilaian & 3 & $1,2,3$ \\
\hline & Penilaian & Pelaksanaan penilaian & 3 & $4,5,6$ \\
\hline \multirow[t]{5}{*}{5} & Pelaksanaan & Penginformasian sistem penilaian & 2 & 1,2 \\
\hline & Penilaian & & & \\
\hline & Kompetensi & & & \\
\hline & Pengetahuan & & & \\
\hline & & Pelaksanaan penilaian & 3 & $3,4,5$ \\
\hline \multirow[t]{4}{*}{6} & Pelaksanaan & Penginformasian sistem penilaian & 3 & $1,2,3$ \\
\hline & Penilaian & Pelaksanaan penilaian & 2 & 4,5 \\
\hline & Kompetensi & & & \\
\hline & Keterampilan & & & \\
\hline \multirow[t]{3}{*}{7} & Manajemen Hasil & Pengolahan nilai & 4 & $1,2,3,4$ \\
\hline & Penilaian & Pelaporan & 2 & 5,6 \\
\hline & Kompetensi Sikap & Tindak lanjut & 2 & 7,8 \\
\hline \multirow[t]{4}{*}{8} & Manajemen Hasil & Pengolahan nilai & 3 & $1,2,3$ \\
\hline & Penilaian & Pelaporan & 3 & $4,5,6$ \\
\hline & Kompetensi & Tindak lanjut & 2 & 7,8 \\
\hline & Pengetahuan & & & \\
\hline
\end{tabular}




\begin{tabular}{|c|c|c|c|c|}
\hline No & Komponen & Indikator & Jumlah Butir & No. Item \\
\hline \multirow[t]{3}{*}{9} & Manajemen Hasil & Pengolahan nilai & 4 & $1,2,3,4$ \\
\hline & Penilaian & Pelaporan & 3 & $5,6,7$ \\
\hline & $\begin{array}{l}\text { Kompetensi } \\
\text { Keteramnilan }\end{array}$ & Tindak lanjut & 1 & 8 \\
\hline
\end{tabular}

Data yang diperoleh dari hasil observasi berupa informasi tentang kemampuan guru dalam melaksanakan asesmen autentik. Setelah data dalam penelitian ini terkumpul, selanjutnya dianalisis menggunakan analisis statistik deskriptif. "Metode analisis statistik deskriptif adalah cara pengolahan data yang dilakukan dengan jalan menerapkan rumus-rumus statistik deskriptif seperti angka rata-rata (Mean) untuk menggambarkan keadaan suatu objek tertentu sehingga diperoleh kesimpulan umum" ((Agung, 2014) Dalam penelitian ini hasil yang dicari adalah nilai rata-rata dan rata-rata persen yang diguanakn untuk mengetahu tingkat kemampuan guru.

Untuk mengetahui tingkat keberhasilan yang dapat dicapai pada sebuah tindakan, maka perlu ditentukan kriteria keberhasilan yang dapat diamati dari indikator-indikator ketercapaian. Kriteria keberhasilan penelitian ini dapat diukur dari ketercapaian peningkatan kemampuan guru melaksanakan asesmen autentik, setelah pelaksanaan bimbingan berkelanjutan. Penelitian ini dikatakan berhasil apabila kemampuan guru dalam melaksanakan asesmen autentik secara individu telah mencapai rata-rata $\geq 75$, dan tingkat kemampuan guru melaksanakan asesmen autentik sebesar $75 \%$ yang berada pada kategori baik..

\section{Hasil dan pembahasan}

Berdasarkan hasil observasi pada melaksanakan asesmen autentik pada prasiklus diperoleh nilai rata-rata sebesar 62,72 dengan rata-rata sebesar 62,72\% yang berarti bahwa kemampuan guru melaksanakan asesmen autentik pada prasiklus tergolong kurang. Untuk meningkatkan kemampuan guru dalam melaksanakan asesmen autentik ditempuh dengan menerapkan bimbingan berkelanjutan.

Pada siklus I tahap perencanaan disiapkan intrumen observasi kemampuan guru melaksanakan asesmen autentik yang akan digunakan untuk menilai pelaksanaan asesmen autentik yang dilakukan oleh guru. Tahap pelaksanaan siklus I berlangsung dalam 4 tahap. Tahap pertama menilai perencanaan asesmen autentik yang disusun guru, tahap kedua menilai pelaksanaan asesmen autentik, tahap ketiga menilai menajamen hasil penilaian asesmen autentik, dan tahap keempat merekap hasil penilaian. Berdasarkan hasil obervasi kemampuan guru melaksanakan asesmen autentik diperoleh rata-rata sebesar 69,59 dengan rata-rata persen sebesar 69,59\% yang berarti bahwa kemampuan guru melaksanakan asesmen autentik pada siklus I tergolong baik.

Berdasarkan hasil observasi dan analisis data siklus I terlihat ada peningkatan kemampuan guru melaksanakan asemen autentik. Sebelum dilaksanakan bimbingan berkelanjutan nilai rata-rata kemampuan guru sebesar 62,72 dan setelah tindakan terjadi peningkatan menjadi 69,59. Hal ini disebabkan karena guru menerima bimbingan yang berkelanjutan dari kepala sekolah. Bimbingan dilakukan secara indovidu, sehingga guru leluasa mengemukakan permasalahan yang dihadapi dalam melaksanakan asesmen autentik, sehingga kepala sekolah bisa memberikan pemecahan masalah tersebut.

Kendala yang ditemukan pada siklus I adalah beberapa guru kurang paham bagaimana melaksanakan penilaian sikap, guru merasa diawasi ketika kepala sekolah menilai asesmen yang mereka susun atau laksanakan. Solusi yang dilakukan adalah memberikan pemahaman bagaimana cara melaksanakan asesmen autentik, dan memberikan motivasi kepada guru agar mau mengemukakan permasalahan yang mereka temui tanpa ada rasa sungkan kepada kepala sekolah.

Pada siklus II tahap perencanaan disiapkan intrumen observasi pelaksanaan proses pembelajaran yang akan digunakan untuk menilai kemampuan guru melaksanakan asesmen autentik oleh guru. Tahap pelaksanaan siklus II berlangsung dalam 4 tahap. Tahap pertama menilai perencanaan asesmen autentik yang disusun guru, tahap kedua menilai pelaksanaan asesmen autentik, tahap ketiga menilai menajamen hasil penilaian asesmen autentik, dan tahap keempat merekap hasil penilaian.

Berdasarkan hasil observasi melaksanakan asesmen autentik diperoleh rata-rata sebesar 78,92 dengan rata-rata persen sebesar 78,92\% yang berarti bahwa kemampuan guru melaksanakan asesmen autentik pada siklus II tergolong baik. Berdasarkan hasil observasi dan analisis data siklus II terlihat ada peningkatan dari siklus I. Sebelum dilaksanakan bimbingan berkelanjutan nilai rata-rata kemampuan guru sebesar 62,72 dan setelah tindakan terjadi peningkatan menjadi 69,59. Kemampuan guru tersebut meningkat lagi pada siklus II menjadi 78,92. Hal ini disebabkan karena guru menerima masukan atau penilaian dari peneliti tentang kekurangan dan kelebihan dalam melaksanakan asesmen autentik yang telah mereka lakukan. Guru sudah tidak ragu-ragu lagi dalam mengemukakan permasalahan yang 
dihadapai dalam melaksanakan asesmen autentik karena situasi yang tercipta sudah kondusif. Perkembangan kemampuan guru dalam melaksanakan asesmen autentik dapat dilihat pada tabel 2 berikut.

Tabel 2 Rekap Perkembangan Kemampuan Guru Melaksanakan Asesmen Autentik

\begin{tabular}{ccccc}
\hline No & Siklus & Rata-Rata & Rata-Rata Persen & Kriteria \\
\hline 1 & Pra & 62,72 & $62,72 \%$ & Kurang \\
2 & I & 69,59 & $69,59 \%$ & Cukup \\
3 & II & 78,92 & $78,92 \%$ & Baik \\
\hline
\end{tabular}

Hasil yang diperoleh pada siklus II sesuai dengan penyajian data di atas menunjukkan bahwa kemampuan guru melaksanakan asesmen autentik telah melampaui indikator keberhasilan, sehingga penelitian dihentikan sampai siklus II. Hal ini disebabkan karena penerapan bimbingan berkelanjutan. Pada penilaian kurikulum 2013, guru dituntut mampu melaksankan penilaian pada aspek sikap, pengetahuan, dan keterampilan. Berdasarkan hasil observasi dan analisis data siklus I terlihat ada peningkatan kemampuan guru melaksanakan asemen autentik. Dengan demikian dapat dinyatakan bahwa bimbingan berkelanjutan dapat meningkatkan kemampuan guru SD Negeri 1 Banjar Tegal dalam melaksanakan asesmen autentik.

Penilaian Kurikulum 2013 menerapkan penilaian autentik untuk menilai kemajuan belajar peserta didik yang meliputi sikap, pengetahuan, dan keterampilan. Pada awalnya kemampuan melaksanakan asesmen autentik pada guru SD Negeri 1 Banjar Tegal masih kurang. Kemudian diatasi dengan pelaksanaan bimbingan berkelanjutan. Berdasarlan analisis data menunjukkan bahwa kemampuan guru melaksanakan asesmen autentik dapat meningkat. Melalui bimbingan berkelanjutan dapat mendorong kemampuan masing-masing individu sesuai dengan minatnya, dapat menilai masing-masing peserta dengan berbagai metode penilaian termasuk observasi dan interview, dapat mengikuti lebih dekat setiap perkembangan peserta, bimbingan lebih pada pendekatan personal dibanding dengan training kelompok, peserta merasa lebih termotivasi dan bertanggung jawab untuk melakukan keterampilan yang baru dipelajari karena bimbingan berlangsung terus menerus dan personal.

Guru dibimbing mulai dari perencanaan, pelaksanaan, sampai dengan pengolahan nilai. Baik pada aspek penilaian sikap, pengetahuan, maupun keterampilan. Melalui bimbingan yang dilakukan secara berkelanjutan, guru berani mengemukakan permasalahan atau kendala yang dihadapi, sehingga bisa didiskusikan pemecahannya bersama-sama. Sehingga kemampuan guru dalam melaksanakan asesmen autentik dapat meningkat.

Seperti disebutkan oleh Muniaji (2014) kegiatan bimbingan berkelanjutan bertujuan agar peserta dapat menstimulan pengembangan keterampilan peserta secara individual, membantu peserta menggunakan pekerjaan sebagai pengalaman pembelajaran dengan bimbingan dan mengembangkan professional peserta, memberi kesempatan kepada peserta untuk melengkapi pekerjaan yang diberikan fasilitator dan pada saat yang sama mempersiapkan keterampilan peserta dalam mengambil tanggung jawab dan pekerjaan mendatang, dan meningkatkan kemampuan kemandirian belajar dari peserta dan mengatasi permasalahan yang dihadapi mereka.

\section{Simpulan dan saran}

Berdasarkan hasil analisis dan pembahasan hasil penelitian dapat ditarik kesimpulan bahwa kemampuan guru SD Negeri 1 Banjar Tegal dalam melaksanakan asesmen autentik dapat ditingkatkan melalui penerapan bimbingan berkelanjutan. Hal ini terlihat dari peningkatan kemampuan guru dalam melaksanakan asesmen autentik yaitu sebelum dilaksanakan bimbingan berkelanjutan nilai rata-rata kemampuan guru sebesar 62,72 meningkat pada siklus I menjadi 69,59 dan meningkat lagi pada siklus II menjadi 78,92.

Beberapa saran yang dapat disampaikan adalah bagi guru, hendaknya mampu meningkatkan kemampuan dan keterampilannya dalam melaksanakan penilaian. Bagi kepala sekolah, hendaknya mampu memberikan motivasi kepada guru dalam upaya melakukan berbagai inovasi dan perbaikanperbaikan kualitas pembelajaran, serta peningkatan profesionalismenya. 


\section{Daftar Rujukan}

Agung, A. A. G. (2014). Metodologi Penelitian Pendidikan. Aditya Media Publish.

Amin, N., Bain, \& Suryadi, A. (2016). Pelaksanaan penilaian autentik dalam pembelajaran sejarah Kurikulum 2013 di SMA Negeri 1 Purwareja Klampok Tahun Pelajaran 2015/2016. Indonesian $\begin{array}{lllll}\text { Journal of History } & \text { Education, }\end{array}$ https://journal.unnes.ac.id/sju/index.php/ijhe/article/view/2174

Arifin, Z. (2014). . Evaluasi Pembelajaran: Prinsip Teknik Prosedur. PT Remaja Rosdakarya.

Beata Palmin, Maria Rahayu Anwar, F. N. (2019). Jurnal audi. Jurnal Ilmiah Kajian Ilmu Anak Dan Media Informasi PUD, 3359(1), 63-72.

Hajaroh, S., Islam, U., \& Mataram, N. (2018). Kesulitan Guru Dalam Mengimplementasikan. Jurnal Jurusan PGMI, 10(2), 131-152.

Marhaeni, A. A. I. . (2015). Asesmen Autentik Dan Pendidikan Bermakna: Implementasi Kurikulum 2013. JPI (Jurnal Pendidikan Indonesia), 4(1). https://doi.org/10.23887/jpi-undiksha.v4i1.4889

Palm, T. (2008). Performance Asessment and Authentic Assessment: A Conceptual Analysis of The Literature. Practical Assessment, Research \& Evaluation.

Ruslan, Fauziah, T., \& Alawiyah, T. (2016). Kendala Guru dalam Menerapkan Penilaian Autentik di SD Kabupaten Pidie. Jurnal Ilmiah Mahasiswa Pendidikan Guru Sekolah Dasar, 1(1), 147-157. https://media.neliti.com/media/publications/188254-ID-kendala-guru-dalam-menerapkanpenilaian.pdf

Sahertian, A. P. (2008). Konsep Dasar dan Teknik Supervisi. Penerbit Rineka Cipta.

Suharningsih, S. (2016). Pelaksanaan Bimbingan Berkelanjutan Sebagai Upaya Meningkatkan Kompetensi Guru Dalam Menyusun Rencana Pelaksanaan Pembelajaran Di Sd N Bandungrejo 1 Pada Semester Gasal Tahun Pelajaran 2014/2015. Jurnal Penelitian PendidikanA \& A (Semarang), 33(1), 83-92. https://doi.org/10.15294/jpp.v33i1.7673

Yusuf, M. (2015). ASESMEN DAN EVALUASI PENDIDIKAN Pilar Penyedia Informasi dan Kegiatan Pengendalian Mutu Pendidikan. In 1. Prenadamedia Group.

Zahro, I. F. (2015). Penilaian dalam Pembelajaran Anak Usia Dini. Tunas Siliwangi, 1(1), 92-111. 